\title{
KUALITAS PELAYANAN DI JURUSAN TEKNIK SIPIL FT.UNJ DARI SUDUT \\ PANDANG MAHASISWA SEBAGAI PELANGGAN
}

Ir. Irika Widiasanti, MT.

\begin{abstract}
ABSTRAK
Penelitian ini merupakan upaya perbaikan kualitas manajemen di Jurusan Teknik Sipil Fakultas Teknik Universitas Negeri Jakarta (JTS-FT-UNJ). Secara khusus mengkaji faktor-faktor yang mempengaruhi kualitas pelayanan dan hubungannya dengan kepuasan layanan dari sudut pandang mahasiswa sebagai pelanggan.

Penelitian dilaksanakan pada periode Agustus sampai Oktober 2004. Penjaringan data pada periode 01 - 15 Oktober 2004 dengan sampel 95 dari 607 mahasiswa dan diambil secara acak melalui metode survey dengan instrumen yang dibuat berdasarkan teori yang berhubungan dengan maksud penelitian. Untuk menjabarkan data sehingga dapat di informasikan menggunakan metode deskriptif dan analisis faktor, sedangkan metode korelasi dilakukan untuk menguji hipotesis yang menyatakan kekuatan hubungan antar variabel.

Pada taraf signifikasi 0,05 , pengujian kelayakan data menggunakan Bartlett Test of Sphercity memberikan 816,420 dan Kaiser-Meyer-Olkin of Sampling Adequacy sebesar 0,747. Pengujian keandalan alat ukur dengan skala alpha memberikan 0,8420 berarti memuaskan. Penilaian responden dengan analisis faktor terhadap kualitas layanan memberikan sembilan faktor dengan hanya enam faktor yang nilai alpha $\geq 0,5$ yaitu faktor kemampuan-nyata fasilitas $\left(F_{1}\right)$, jaminan pengetahuan $\left(F_{2}\right)$, kualitas laboratorium $\left(F_{5}\right)$, jaminan ketrampilan $\left(F_{6}\right)$, empati dalam berkomunikasi $\left(F_{7}\right)$, dan keandalan waktu penyelesaian studi $\left(F_{9}\right)$. Dengan hubungan; $\quad Y=0,493$ $F_{1}+0,448 F_{2}+9,14710^{-2} F_{5}+0,146 F_{6}+0,124 F_{7}+0,185 F_{9}-4.555$ $10^{-16}$. Kekuatan hubungan 0,724 dengan $49,1 \%$ variasinya.
\end{abstract}


Kata Kunci: Kualitas Pelayanan, Mahasiswa, Pelanggan, Analisis Faktor

\section{PENDAHULUAN}

Upaya peningkatan kinerja pendidikan dapat dilakukan melalui pengembangan manajemen dengan mengacu fokus pasar sasaran, yakni kebutuhan akan sumber daya manusia yang berkualitas. Penerapan pola pelayanan yang tepat memerlukan pengetahuan mengenai beberapa perbedaan persepsi dan tanggapan mahasiswa sebagai konsumen. Kriteriakriteria kepuasan atas pelayanan yang ditawarkan (supply) di organisasi sesuai dengan harapan atau melebihi harapan mahasiswa (demand). Parasuraman et al., (1990) menyimpulkan ada 5 (dimensi yang dipakai pelanggan dalam menilai suatu kualitas layanan, yaitu: tangible, reliability, responsiveness, empathy dan assurance. Dan sangat dipengaruhi oleh persepsi, menurut Zeithaml dan Bitner (1996), faktor-faktor yang mempengaruhi persepsi pelanggan terhadap kualitas layanan, ada 4 faktor, yaitu; (a) service encounters yaitu layanan yang terjadi pada saat pelanggan berinteraksi dengan pelayanan perusahaan. (b) the evidence of service yaitu keinginan pelanggan untuk mencari kehadiran layanan dalam setiap interaksi, (c) Image yaitu ingatan yang ada dalam persepsi pelanggan, dan (d) Price yaitu harga yang dikeluarkan untuk pelayanan yang diterima.

Faktor-faktor tersebut akan menyebabkan kondisi pasar bagi penyedia jasa pendidikan di masa depan sangat kompetitif. Lembaga pendidikan yang dikelola pemerintah tidak akan dapat dapat bersaing tanpa meningkatkan pola pelayanan yang tepat yang memerlukan pengetahuan mengenai beberapa perbedaan persepsi mahasiswa, kriteria-kriteria mengenai kepuasan. Filosofi ini akan berusaha melihat segala sesuatu yang berhubungan dengan prilaku dan memenuhi keinginan mahasiswa untuk menjamin kesuksesan dari program jangka panjang.

\section{Indentifikasi dan Perumusan Masalah}

Berdasarkan uraian diatas muncul pertanyaan; (a) Bagaimanakah peran jurusan teknik sipil dalam menghasilkan sdm berkualitas dilihat dari sisi kebutuhan tenaga teknik sipil? (b) Bagaimanakah kualitas manajemen pelayanan jurusan teknik sipil? (c) Bagaimanakah persepsi pelayanan atas kepuasan pelanggan dilihat dari sisi mahasiswa sebagai pengguna/pelangan? (d) Apakah pelayanan yang diterima mahasiswa telah memenuhi aspek kualitas pelayanan? (e) Faktor-faktor apa saja yang membentuk kualitas pelayanan.

Semua permasalahan di atas perlu untuk diteliti dan dikaji lebih mendalam. Akan tetapi dalam hal ini peneliti hanya menitik beratkan pada

Kualitas Pelayanan di Jurusan Teknik Sipil FT-UNJ Dari Sudut Pandang Mahasiswa Sebagai Pelanggan.(Irika Widiasanti, Dosen Jurusan Teknik Sipil FTUNJ) 
aspek kualitas pelayanan dilihat dari sisi mahasiswa berdasarkan persepsi mereka akan kepuasan pelanggan? Sehingga masalahnya dapat dirumuskan sebagai berikut, (a) Bagaimanakah faktor-faktor kualitas pelayanan jurusan teknik sipil termasuk faktor apa saja yang mempengaruhi kualitas pelayanan tersebut? (b) apakah mahasiswa telah merasa puas terhadap pelayanan yang mereka terima? (c) bagaimana hubungan faktor pelayanan dengan kepuasan mahasiswa?

2. Tujuan Penelitian

Secara umum tujuan penelitian untuk perbaikan internal manajemen dan organisasi jurusan sebagai dasar evaluasi diri (selfevaluation) dalam upaya penyusunan proposal-proposal kompetisi. Secara khusus; (a) menentukan dan mengidentifikasikan faktor yang membentuk kualitas pelayanan di jurusan teknik sipil FT.UNJ dari sudut pandang mahasiswa, (b) mengkaji kepuasan mahasiswa atas layanan sebagai pelanggan, (c) mengkaji pengaruh pembentuk faktor kualitas layanan atas kepuasan mahasiswa atas layanan yang diterima.

\section{A. LANDASAN TEORI}

\section{Kualitas Pelayanan}

Lembaga pendidikan merupakan sebuah produk jasa. Ciri-ciri produk jasa antara lain adalah; a) Tidak nyata (intangibility) yaitu jasa tidak dapat dilihat, dirasa, didengar atau tidak dapat diindentifikasi oleh panca indera sebelum produk jasa dibeli. Untuk merasakan maka konsumen mencari sendiri bukti, sesuai dengan persepsi pelanggan. b) Keragamaman (variability), yaitu tergantung siapa dan kepada siapa produk ditawarkan. c) Tidak tahan lama (perishability). Agar dapat dihasilkan sebuah produk jasa yang berkualitas maka pemamahaman akan kualitas pelayanan menjadi penting melalui pemahaman perilaku konsumen yang dalam perspektif ekonomi tergantung dari pasar, atau sasaran produk yang ditawarkan. (Wells and Prensky, 1996). Kualitas pelayanan dipengaruhi oleh kepuasan. Dua difinisi kepuasan pengguna adalah; (a) persepsi pengguna terhadap suatu jenis pelayanan yang didapatkan (Parasuraman, et al, 1990); dan (b) kepuasan adalah kunci untuk mendapatkan keuntungan jangka panjang dan 
tetap memberikan kenyamanan pada pengguna adalah merupakan kebutuhan bisnis setiap orang (Milind dan Jugdis, 1990). Kualitas pelayanan merupakan reflkesi dari lima faktor dimensi spesifik kualitas layanan, hubungannya disajikan dalam gambar 1. (Parasuraman et al., 1990) yaitu: (a) Tangible (Kemampu-nyataan), yaitu penampilan fisik, peralatan, personil, dan materi komunikasi. (b) Reliability, (kemampu-ujian) yaitu kemampuan untuk memberikan layanan yang dijanjikan secara akurat, tepat waktu, dan dapat dipercaya. (c) Responsiveness (Kemampuauan-tanggapan) yaitu untuk membantu pelanggan dengan memberikan layanan yang baik dan cepat. (d) Empathy yaitu berusaha untuk mengetahui dan mengerti kebutuhan pelanggan secara individual. (e) Assurance (jaminan) yaitu pengetahuan dan keramah tamahan pelayanan untuk menjamin kepuasan yang dipercaya dan diyakini. Jika dilihat mahasiswa sebagai pengguna maka kualitas pelayanan merupakan persepsi apa yang diterima dan dirasakan oleh mahasiswa terhadap pelayanan jurusan.

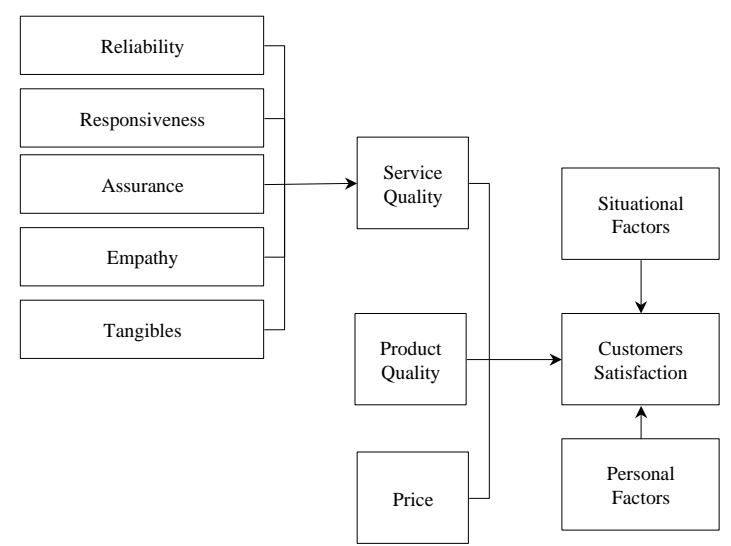

Gambar 1. Customer Perception of Quality and Customer Satisfaction Sumber : Valarie A. Zethaml, Mary Jo Bitner “Service Marketing” (1996), p.123

\section{Analisis Faktor}

Analisis faktor merupakan salah satu prosedur reduksi data serta salah satu alat untuk mengkaji validitas alat ukur dalam metode statistik multivariat. Tiga fungsi utamanya (Dillon dan Goldstein, 1984), yaitu: a) Mereduksi banyaknya variabel penelitian dengan tetap mempertahankan sebanyak mungkin informasi dari data awal. Banyaknya variabel awal dapat dikurangi menjadi

Kualitas Pelayanan di Jurusan Teknik Sipil FT-UNJ Dari Sudut Pandang Mahasiswa Sebagai Pelanggan.(Irika Widiasanti, Dosen Jurusan Teknik Sipil FTUNJ) 
beberapa variabel yang jumlahnya sedikit dengan tetap mempertahankan sebagian besar variasi data, b) Mencari perbedaan kuantitatif dan kualitatif terhadap data, bila terdapat jumlah data yang sangat besar, c) Menguji hipotesis tentang perbedaan kuantitatif dan kualitatif dalam data penelitian secara uji statistik yang memuaskan dan dapat dipercaya jika peneliti hanya berdasarkan teori daripada kenyataan (a priori) dari hipotesis terhadap sejumlah dimensi atau karakter dari dimensi.

Analisis faktor dimaksudkan untuk menjamin item-item pertanyaan dalam kuesioner dapat mempresentasikan dengan baik variabel-variabel laten yang diselidiki. Dengan demikian dapat diketahui variabel manifes yang membentuk variabel laten. Hubungan yang komplek dan beragam diantara sekumpulan variabel penelitian diperoleh dengan jalan mengungkap dimensi atau faktor yang sama (common faktors) sehingga dapat menghubungkan variabel-variabel tersebut, serta memperlihatkan struktur laten dari data penelitian (Chatfield dan Collins, 1992).

Variabel laten yang diselidiki merupakan suatu bentuk penelitian penjelasan (explainatory research). Sehingga analisis faktor yang dipakai merupakan salah satu bentuk justifikasi yang merujuk akan penilaian individu akan kualitas pelayanan yang mereka dapat selama menjadi mahasiswa di lingkungan Jurusan Teknik Sipil - Fakultas Teknik Universitas Negeri Jakarta. Analisis faktor didasarkan atas keyakinan bahwa variabel yang di observasi sebagian besar memiliki interkorelasi, hal ini memungkinkan keberadaan faktor umum yang mendasari keteraturan data. Faktor umum yang dimiliki bersama antar variabel yang diamati disebut common faktor dan faktor yang membedakan variabel satu dengan yang lainnya adalah unique faktor. Asumsi penting yangg digunakan dalam analisis, sebagai berikut; (a) keunikan masingmasing variabel tidak memberikan kontribusi pada hubungan antar variabel. (b) Faktor-faktor yang terbentuk dalam analisis bersifat bebas satu dengan lainnya.

\section{B. METODOLOGI PENELITIAN}

Penelitian ini bersifat penjelasan dengan lokasi penelitian di Jurusan Teknik Sipil Fakultas Teknik Universitas Negeri Jakarta, dilaksanakan pada Agustus - Oktober 2004. Penjaringan data melalui 
instrumen questioner meliputi lima dimensi kualitas pelayanan. Sampel sebanyak 92 dari 607 mahasiswa. Metode deskriptif untuk menjabarkan data dan metode analisis faktor untuk menentukan faktor kualitas pelayanan. Regresi untuk mengkaji hubungan antara kualitas layanan dengan kepuasan pengguna.

\section{Instrumen Penelitian}

Instrumen menggunakan kuestioner yang memuat daftar pertanyaan seperti di tabel 2.

Tabel 2. Kode dan Variabel untuk Analisis Faktor

\begin{tabular}{|c|c|c|}
\hline Kode & $\begin{array}{l}\text { Indikator Pertanyaan } \\
\text { (Variabel Manifes) }\end{array}$ & $\begin{array}{l}\text { Faktor } \\
\text { (Variabel Laten) }\end{array}$ \\
\hline $\mathrm{X} 1$ & Sarana ruang kelas, & \multirow{8}{*}{$\begin{array}{l}\text { Tangibility } \\
\text { (kemampuan-nyata) }\end{array}$} \\
\hline $\mathrm{X} 2$ & Laboratorium, & \\
\hline X3 & Peralatan laboratorium & \\
\hline $\mathrm{X} 4$ & $\begin{array}{l}\text { Kenyamanan fasilitas ruang kegiatan } \\
\text { mahasiswa (UKM) }\end{array}$ & \\
\hline X5 & Kualitas dosen & \\
\hline $\mathrm{X} 6$ & Kualitas tenaga laboran & \\
\hline $\mathrm{X} 7$ & Kualitas tenaga administrasi & \\
\hline $\mathrm{X} 8$ & $\begin{array}{l}\text { Kemudahan menggunakan fasilitas } \\
\text { jurusan. }\end{array}$ & \\
\hline X9 & Ketepatan jadwal waktu kuliah & \multirow{6}{*}{ Keandalan (reliability) } \\
\hline $\mathrm{X} 10$ & $\begin{array}{l}\text { Pengisian Kartu Rencana Studi (KRS) } \\
\text { atau Waktu Perkuliahan }\end{array}$ & \\
\hline $\mathrm{X} 11$ & Jadwal ujian tengah semester & \\
\hline $\mathrm{X} 12$ & Jadwal ujian akhir semester & \\
\hline $\mathrm{X} 13$ & Penerimaan Lembar Hasil studi (KHS), & \\
\hline $\mathrm{X} 14$ & Ketepatan Waktu penyelesaian studi. & \\
\hline $\mathrm{X} 15$ & Pelayanan personil dosen & Keecepatan \\
\hline
\end{tabular}

Kualitas Pelayanan di Jurusan Teknik Sipil FT-UNJ Dari Sudut Pandang Mahasiswa Sebagai Pelanggan.(Irika Widiasanti, Dosen Jurusan Teknik Sipil FTUNJ) 


\begin{tabular}{|c|c|c|}
\hline $\mathrm{X} 16$ & Pelayanan tenaga administrasi & \multirow[t]{2}{*}{ (responsiveness) } \\
\hline X17 & Pelayanan Tenaga laboran & \\
\hline X18 & Prilaku dosen & \multirow{5}{*}{ Jaminan (assurance) } \\
\hline X19 & Prilaku tenaga administrasi & \\
\hline X20 & Prilaku laboran & \\
\hline $\mathrm{X} 21$ & $\begin{array}{l}\text { Jaminan pengetahuan yang didapat } \\
\text { setelah lulus }\end{array}$ & \\
\hline X22 & $\begin{array}{l}\text { Jaminan ketrampilan yang didapat } \\
\text { (kompetensi) setelah lulus }\end{array}$ & \\
\hline X23 & $\begin{array}{l}\text { kemudahan dosen untuk dihibungi melalui } \\
\text { telepon }\end{array}$ & \multirow{4}{*}{ Empati } \\
\hline X24 & keberadaan dosen yang mudah dijangkau & \\
\hline X25 & $\begin{array}{l}\text { Kemudahan menghubungi tenaga } \\
\text { administrasi }\end{array}$ & \\
\hline X26 & Kemudahan menghubungi tenaga laboran & \\
\hline Y & $\begin{array}{l}\text { Penilaian Kualitas Pelayanan Secara } \\
\text { Menyeluruh }\end{array}$ & Variabel terikat \\
\hline
\end{tabular}

\section{Analisis Faktor}

Analisis faktor menggunakan alat bantu program komputer SPSS. Tahapan analisis faktor mengikuti diagram alir pada gambar 2. 


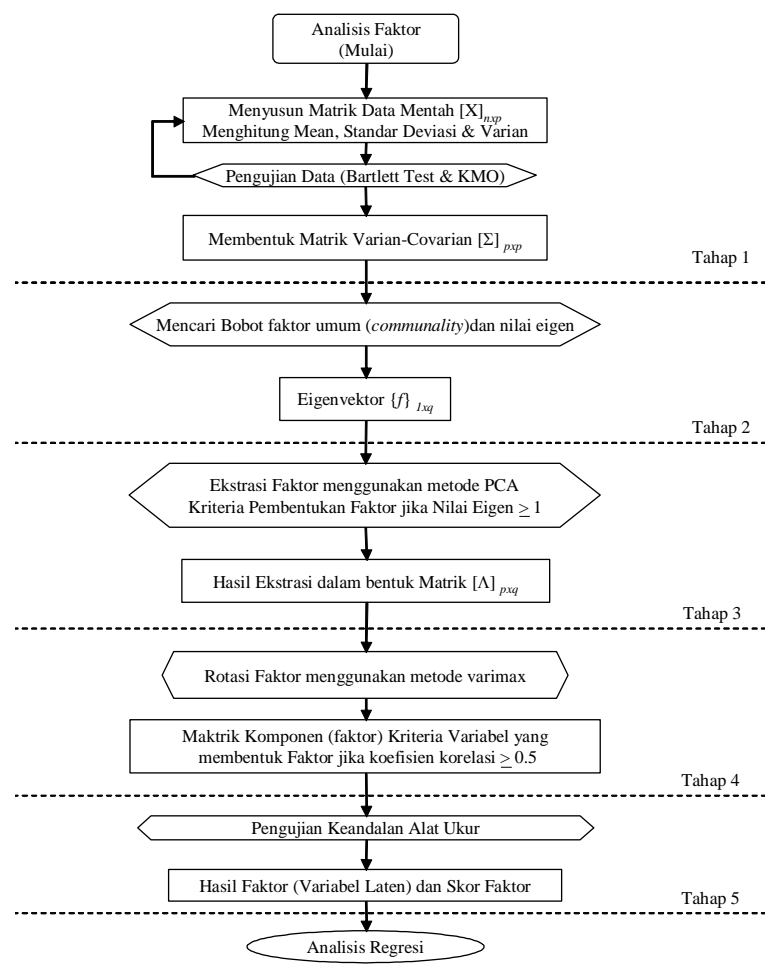

Gambar 2. Diagram Alir Analisis Faktor

3. Hipotesis Penelitian

Kesesuaian Penggunaan Analisis Faktor dengan melakukan uji Bartlett Test of Sphericity $(X)$ dengan Rata-rata Chi-Square Test dan Kaiser-Meyer-Olkin Measure of Sampling (MSA).

Hipotesis

$\mathrm{H}: X=0$ : variabel yang diamati dan responden yang diamati adalah independent (bebas)

$\mathrm{H}: \mathrm{X} \neq 0$ : variabel yang diamati dan responden tidak bebas (dependent)

\section{Hipotesis}

$\mathrm{H}: M S A=1.0: \quad$ variabel dan responden yang diamati adalah tidak mempunyai kesalahan

$\mathrm{H}: M S A>0.5$ : variabel dan responden yang diamati masih mempunyai kesalahan dan dapat diprediksi dan analisis lebih lanjut.

$\mathrm{H}: M S A<0.5$ : variabel dan responden yang diamati mempunyai kesalahan yang besar dan tidak dapat diprediksi serta analisis lebih lanjut.

Untuk keandalan alat ukur kualitas pelayanan diuji konsistensinya

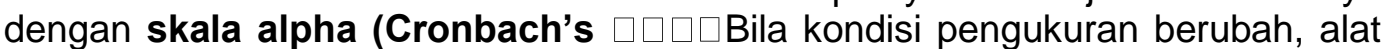
ukur yang andal akan berlaku sama. Asumsi yang digunakan, alat ukur yang diuji berkorelasi positif (Norusisb, 1993:147).

Hipotesis

Kualitas Pelayanan di Jurusan Teknik Sipil FT-UNJ Dari Sudut Pandang Mahasiswa Sebagai Pelanggan.(Irika Widiasanti, Dosen Jurusan Teknik Sipil FTUNJ) 
$\mathrm{H}: \square=1.0$ : Alat ukur (faktor) dapat digunakan untuk mengukur kualitas pelayanan.

$\mathrm{H}: \square \square<0.5$ : Alat ukur (faktor) tidak dapat digunakan untuk mengukur kualitas pelayanan.

Hubungan Regresi Hipotesisnya adalah

$$
\begin{aligned}
& H_{0}: \square_{x, y}=0 \\
& H_{0}: \square_{x, y} \neq 0 \\
& \square_{x, y} \quad \begin{aligned}
\text { koefisien korelasi antara variabel bebas }(X) \text { dengan variabel } \\
\text { terikat }(Y) .
\end{aligned}
\end{aligned}
$$

\section{HASIL PENELITIAN DAN PEMBAHASAN}

1. Deskripsi Data Responden

Deskripsi data berdasarkan jenis kelamin responden terbagi menjadi 48,4\% Perempuan dan $51,6 \%$ Laki-laki, memenuhi keterwakilan penilaian atas jenis kelamin.

Distribusi responden berdasarkan program studi yaitu mahasiswa D3-

\begin{tabular}{|c|c|c|c|}
\hline Variabel Manifes & $\begin{array}{l}\text { Nilai } \\
\text { Tengah }\end{array}$ & $\begin{array}{l}\text { Deviasi } \\
\text { Standar }\end{array}$ & $\begin{array}{l}\text { Varian } \\
\text { Sampel }\end{array}$ \\
\hline X1 Sarana ruang kelas & 2.69 & .85 & .725 \\
\hline X2 Sarana Laboratorium & 2.35 & .80 & .633 \\
\hline X3 Peralatan Laboratorium & 1.78 & .84 & .706 \\
\hline $\begin{array}{l}\text { X4 kenyamanan Fasilitas R.Kegiatan } \\
\text { Mahasiswa (UKM) }\end{array}$ & 2.98 & .70 & .489 \\
\hline X5 Kualitas Dosen & 3.23 & .88 & .776 \\
\hline X6 Kualitas Tenaga Laboran & 2.08 & .83 & 695 \\
\hline X7 Kualitas Tenaga Adminitrasi & 1.83 & 66 & 439 \\
\hline $\begin{array}{l}\text { X8 Kemudahan Menggunakan fasilitas } \\
\text { Jurusan }\end{array}$ & 2.43 & .83 & 695 \\
\hline X9 Ketepatan Jadwal Kuliah & 3.13 & 67 & .452 \\
\hline X10 Ketepatan Pengisian KRS & 3.11 & 69 & 478 \\
\hline X11 Jadwal UTS & 3.32 & .96 & .920 \\
\hline X12 Jadwal UAS & 2.84 & .93 & .858 \\
\hline X13 Waktu Penerimaan KHS & 3.02 & .79 & 617 \\
\hline X14 Ketepatan Waktu Studi & 2.78 & .92 & .855 \\
\hline
\end{tabular}
Transportasi (42,1\%), D3-Teknik Sipil 25,3\% dan S1-Pendidikan TS 32,6\%.

\section{Deskripsi Analisis Faktor}

Tabel 3. Deskripsi Statistik Variabel Analisis Faktor

MENARA, JURNAL TEKNIK SIPIL VOL. I, NO. 1, JANUARI 2006 ;96-111 


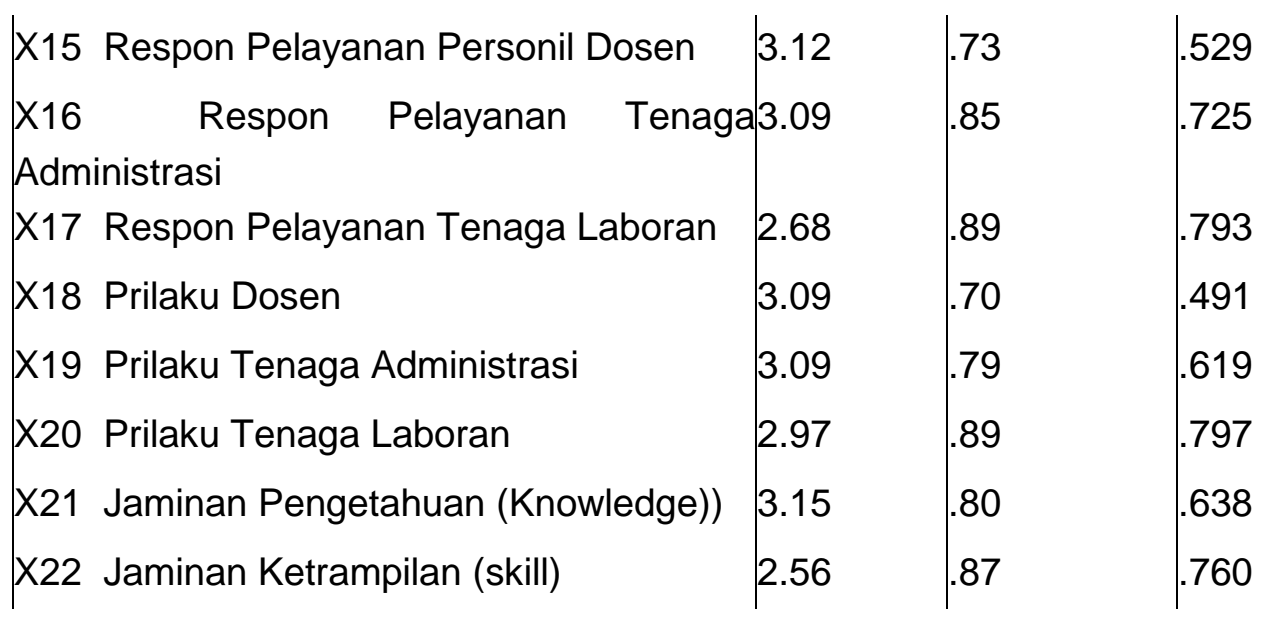

Tabel 4. Deskripsi Statistik Variabel Analisis Faktor (lanjutan)

\begin{tabular}{|c|c|c|c|}
\hline Variabel Manifes & $\begin{array}{l}\text { Nilai } \\
\text { Tengah }\end{array}$ & $\begin{array}{l}\text { Deviasi } \\
\text { Standar }\end{array}$ & $\begin{array}{l}\text { Varian } \\
\text { Sampel }\end{array}$ \\
\hline X23 Kemudahan di hubungi via Telepon & 3.13 & .96 & .920 \\
\hline X24 Keberadaan yg mudah di Jangkau & 3.20 & .83 & .694 \\
\hline X25 Kemudahan menghubungi Tenaga Adm & 3.14 & .81 & .651 \\
\hline $\begin{array}{l}\text { X26 } \begin{array}{l}\text { Kemudahan Menghubungi Tenaga } \\
\text { Laboran }\end{array} \\
\text { Y Pelayanan Keseluruhan }\end{array}$ & 3.25 & .87 & .765 \\
\hline
\end{tabular}

\section{Pengujian Persyaratan Analisis Faktor}

Pengujian persyaratan analisis memberikan Angka Bartlett Test 816.420 >> nilai tabel signifikasi 0.001 . Maka data dapat digunakan untuk analisis lebih lanjut. Harga KMO 0.747 adalah cukup memuaskan. Analisis keandalan alat ukur menggunakan skala alpha di dapat nilai alpha 0.8420 merupakan angka memuaskan maka variabel dapat digunakan untuk analisis faktor.

\section{Hasil Analisis Faktor}

Dari matrik data mentah varian-kovarian, dilakukan pembobotan faktor untuk mencari nilai eigen. Hasil ektrasi faktor menggunakan metode Principal Componen Analisys (PCA) dan rotasi hasil ekstrasi menggunakan metode varimax, hasilnya disajikan di Tabel 4 . Kekuatan hubungannya dinyatakan dalam matrik korelasi sepeti Tabel 5.

Tabel 5. Variabel Manifes Pembentuk Faktor Hasil Rotasi

\begin{tabular}{|l|l|l|l|}
\hline Faktor & Variabel Manifes & Korelasi & Label \\
\hline
\end{tabular}

Kualitas Pelayanan di Jurusan Teknik Sipil FT-UNJ Dari Sudut Pandang Mahasiswa Sebagai Pelanggan.(Irika Widiasanti, Dosen Jurusan Teknik Sipil FTUNJ) 


\begin{tabular}{|c|c|c|c|}
\hline 1 & $\begin{array}{l}\text { X4 } \text { kenyamanan Fasilitas R.Kegiatan Mahasiswa } \\
\text { (UKM) } \\
\text { X5 } \\
\text { X8 }\end{array}$ & $\begin{array}{l}682 \\
689 \\
.542 \\
613 \\
626 \\
.529 \\
.770 \\
.635\end{array}$ & Fasilitas \\
\hline 2 & 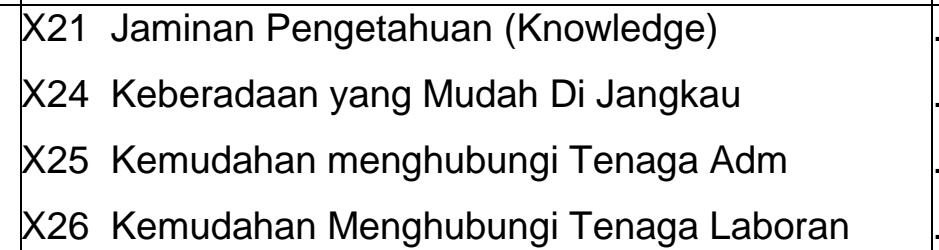 & $\begin{array}{l}676 \\
.579 \\
579 \\
.703\end{array}$ & $\begin{array}{l}\text { Jaminan } \\
\text { Pengetahuan } \\
\text { (knowledge) }\end{array}$ \\
\hline 3 & $\begin{array}{l}\text { X10 Ketepatan Pengisisan KRS } \\
\text { X12 Jadwal UAS }\end{array}$ & $\begin{array}{l}.510 \\
.801\end{array}$ & UAS \\
\hline 4 & $\begin{array}{ll}\text { X6 } & \text { Kualitas Tenaga Laboran } \\
\text { X7 } & \text { Kualitas Tenaga Adminitrasi }\end{array}$ & $\begin{array}{l}.793 \\
590\end{array}$ & Adm \\
\hline 5 & $\begin{array}{ll}\text { X2 } & \text { Sarana Laboratorium } \\
\text { X3 } & \text { Peralatan Laboratorium }\end{array}$ & $\begin{array}{l}.849 \\
.821\end{array}$ & Lab. \\
\hline 6 & X22 Jaminan Ketrampilan (skill) & 844 & Skill \\
\hline 7 & X23 Kemudahan di hubungi via Telepon & 888 & Komunikasi \\
\hline 8 & $\begin{array}{l}\text { X1 } \text { Sarana ruang kelas } \\
\text { X11 Jadwal UTS } \\
\text { X17 } \text { Respon Pelayanan Tenaga Laboran }\end{array}$ & $\begin{array}{l}.799 \\
.408 \\
463\end{array}$ & R.Kelas \\
\hline 9 & X14 Ketepatan Waktu Studi & .846 & Waktu Studi \\
\hline
\end{tabular}

Tabel 6. Matrik Faktor

\begin{tabular}{|l|lllllllll|}
\hline Faktor & 1 & 2 & 3 & 4 & 5 & 6 & 7 & 8 & 9 \\
\hline 1 & .780 & .412 & .303 & .217 & .090 & .001 & .048 & .042 & .264 \\
2 & -.264 & .216 & .216 & .053 & .375 & .541 & .388 & .484 & -.130 \\
3 & -.284 & .218 & .252 & .405 & .202 & .025 & -.774 & .013 & -.054 \\
4 & -.202 & .628 & -.224 & .083 & -.613 & .296 & .065 & -.197 & .034 \\
5 & -.231 & .368 & -.317 & .126 & .570 & -.359 & .269 & -.368 & .185 \\
\hline
\end{tabular}




$\begin{array}{llllllllll}6 & .212 & .219 & -.418 & -.642 & .273 & .263 & -.408 & .098 & .006 \\ 7 & .118 & -.364 & -.515 & .494 & .066 & .434 & -.051 & .011 & .387 \\ 8 & .016 & -.160 & .359 & -.154 & .155 & .482 & .030 & -.751 & -.022 \\ 9 & .297 & .027 & -.279 & .288 & .085 & .037 & .039 & -.124 & -.851\end{array} \mid$

Dari tabel 5 dan 6 dapat disimpulkan; Faktor Pertama diberi nama Fasilitas merupakan agregasi yang menghasilkan variabel laten atau faktor, yaitu gabungan dari variabel manifes di duga akan membentuk lima faktor kualitas layanan. Koefisien transformasi matrik +0.780 menyatakan penilaian responden atas kualitas pelayanan terbentuk dari $\mathrm{X}_{4}$ (kenyamanan Fasilitas R.Kegiatan Mahasiswa/UKM), $X_{5}$ (Kualitas Dosen), $X_{8}$ (Kemudahan Menggunakan fasilitas Jurusan), $X_{9}$ (Ketepatan Jadwal Kuliah), $X_{13}$ (Waktu Penerimaan KHS), $X_{15}$ (Respon Pelayanan Personil Dosen), $X_{16}$ (Respon Pelayanan Tenaga Administrasi) dan $X_{18}$ (Prilaku Dosen). Nilai +0.78 menunjukan semakin tinggi kesan yang di dapat mahasiswa akan kinerja pelayanan dan ketepatan atau kesesuaian waktu pelayanan yang dijanjikan oleh fihak manajemen jurusan terutama dalam hal fasilitas, maka mahasiswa akan berpersepsi semakin positif. Faktor Kedua merupakan agregasi menghasilkan variabel laten yang terbentuk dari variabel manifes yang di awal di duga akan membentuk faktor jaminan dan empati akan lima dimensi kualitas layanan. Selanjutnya di beri nama dengan nama Jaminan Pengetahuan (knowledge). Koefisien transformasi matrik +0.216 dan berdasarkan input varian menunjukan bahwa $21,6 \%$ mahasiswa menilai jaminan akan pengetahuan terbentuk dari $X_{21}$ (Jaminan Pengetahuan/Knowledge), $\mathrm{X}_{24}$ (Keberadaan yang Mudah Di Jangkau) $\mathrm{X}_{25}$ (Kemudahan menghubungi Tenaga Adm) dan $\mathrm{X}_{26}$ (Kemudahan Menghubungi Tenaga Laboran). Faktor ketiga terdiri dari Variabel manifes yaitu $X_{10}$ (Ketepatan Pengisisan KRS), $\quad X_{12}$ (Jadwal UAS), nilai 0,252 menunjukan bahwa 25,2\% mahasiswa menilai perlu ada peningkatan dapal jadwal UAS. Faktor ke empat terbentuk dari $\mathrm{X}_{6}$ (Kualitas Tenaga Laboran), $\mathrm{X}_{7}$ (Kualitas Tenaga Administrasi) sehingga diberi nama Adm dengan 8,3\% pengaruhnya terhadap peningkatan kualitas layanan. Faktor ke lima mempunyai angka korelasi 0,57 terbentuk dari $\mathrm{X}_{2}$ (Sarana Laboratorium) dan $\mathrm{X}_{3}$ (Peralatan 
Laboratorium) menjelaskan bahwa 57\% kualitas pelayanan di pengaruhi oleh kualitas pelayanan laboratorium (Lab). Faktor enam terbentuk dari $\mathrm{X}_{22}$ (jaminan akan ketrampilan) dengan 26,3\% pengaruhnya, dan faktor ke tujuh terbentuk dari $X_{23}$ (Kemudahan dihubungi via telepon) dengan 5,1\% komunikasi berpengaruh terhadap pembentukan kualitas pelayanan secara menyeluruh dan bergerak kearah negatif. Faktor ke delapan terbentuk dari satu Variabel manifes $X_{1}$ (Sarana ruang kelas), $X_{11}$ (Jadwal UTS) dan $X_{17}$ ( Respon Pelayanan Tenaga Laboran) dengan negatif $75,1 \%$ pengaruhnya terhadap pembentukan kualitas pelayanan. Faktor ke sembilan terbentuk dari Variabel $\mathrm{X}_{14}$ (Ketepatan Waktu Studi) dengan angka korelasi faktor -0,851. Dapat diartikan bahwa jika kualitas pelayanan semakin tinggi maka ruang kelas akan lebih optimal dan waktu penyelesaian studi semakin pendek.

\section{Analisis Keandalan Alat Ukur}

Analisis menggunakan reliability skala alpha hasilnya seperti tabel 6 , maka faktor yang tidak dapat digunakan sebagai alat ukur dengan alpha < 0,5 adalah faktor ke3, 4, dan 8.

Tabel 7. Analisis Skala Alpha (Conchran)

\begin{tabular}{|l|l|l|l|}
\hline $\begin{array}{l}\text { Fak- } \\
\text { tor }\end{array}$ & \multicolumn{1}{|c|}{ Deskripsi } & $\begin{array}{l}\text { Variabel Manifes } \\
(\mathrm{k})\end{array}$ & $\begin{array}{c}\text { Alph } \\
\mathrm{a}\end{array}$ \\
\hline 1 & Fasilitas & 8 buah & $\underline{0.8270}$ \\
2 & Jaminan Pengetahuan (knowledge) & 4 buah & $\underline{0.6550}$ \\
3 & UAS & 2 buah & 0.4319 \\
4 & ADM & 2 buah & 0.4787 \\
5 & Lab. & 2 buah & $\underline{0.6358}$ \\
6 & Skill & 1 buah & $\underline{0.8440}$ \\
7 & Komunikasi & 1 buah & $\underline{0.8880}$ \\
8 & R.Kelas & 3 buah & 0.1098 \\
9 & Waktu Studi & 1 buah & $\underline{0.8460}$ \\
\hline
\end{tabular}

MENARA, JURNAL TEKNIK SIPIL VOL. I, NO. 1, JANUARI 2006 ;96-111 


\section{Analisis Regresi}

Analisis regresi dilakukan hanya untuk faktor $1,2,5,6,7$, dan 9 . Hubungan antara hasil faktoring dengan penilaian responden secara menyeluruh terhadap kualitas pelayanan merupakan nilai z-skor. Sehingga variabel terikat $(Y)$ dengan skala Likert $1-5$ agar dapat dibuat model regresi haruslah mempunyai skala yang sama dengan hasil faktor. Maka variabel $Y$ dilakukan tranformasi ke dalam z-skor. Hasil hitungan regresi ditunjukan dengan persamaan sebagai berikut:

$Y=0,493 F_{1}+0,448 F_{2}+9,14710^{-2} F_{5}+0,146 F_{6}+0,124 F_{7}+0,185 F_{9}-4$ $.55510^{-16}$.

Keberartian model diuji dengan menggunakan analisa of varian/Anova (Tabel 7) memberikan nilai $F_{\text {hitung }}(16,127)>F_{\text {tabel }}(2.37)$ sehingga $H_{o}$ pada taraf nyata 0.05 diterima maka model berarti. Koefisien korelasi yang di dapat sebesar 0,724 dengan demikian $H_{0}$ pada taraf nyata 0,05 diterima dimana $F$ hasil hitungan lebih besar dari $F$ Tabel maka secara bersama-sama variabel bebas mempengaruhi variabel terikatnya. Koefisien determinasi yang didapat 0,491 menjelaskan bahwa $49,1 \%$ variasi kualitas pelayanan secara keseluruhan ditentukan oleh variabel bebasnya yaitu pelayanan akan fasilitas, jaminan akan pengetahuan yang di dapat mahasiswa, pelayanan laboratorium, komunikasi sumber daya manusia dan jaminan waktu studi.

Tabel 8 Daftar Anova untuk Regresi

\begin{tabular}{lllll}
\hline & Jumlah Kuadrat Tengah & df & Rata-rata Kuadrat & F \\
\hline Regresi & 49,229 & 6 & 8,205 & 16,127 \\
Sisa & 44,771 & 88 & 0,509 & \\
Jumlah & 94,000 & 94 & & \\
\hline
\end{tabular}

\section{PENUTUP}

Kesimpulan yang dapat diambil adalah, Pertama: Pengujian persyaratan analisis untuk analisa faktor pada taraf signifikasi 0,05 untuk menganalisa keragamanan data menggunakan Bartlett Test of Sphercity dan Kaiser-Meyer-

Kualitas Pelayanan di Jurusan Teknik Sipil FT-UNJ Dari Sudut Pandang Mahasiswa Sebagai Pelanggan.(Irika Widiasanti, Dosen Jurusan Teknik Sipil FTUNJ) 
Olkin of Sampling Adequacy. Angka Bartlett Test dapat diterima. Kedua: Variabel manifes yang di analisis yang diduga akan membentuk lima faktor kualitas pelayanan setelah di analisis membentuk sembilan faktor yaitu: (1) Fasilitas merupakan gabungan dari variabel $X_{4}, X_{5}, X_{8}, X_{9}, X_{13}, X_{15}, X_{16}$ dan $X_{18}$ dengan kekuatan hubungan +0.78 menunjukan semakin tinggi kesan yang di dapat mahasiswa akan kinerja pelayanan dan ketepatan atau kesesuaian waktu pelayanan yang dijanjikan oleh fihak manajemen jurusan terutama dalam hal fasilitas, maka mahasiswa akan berpersepsi semakin baik atau berpersepsi positif. (2) Jaminan Pengetahuan (knowledge) merupakan agregasi variabel $\mathrm{X}_{21}$, $X_{24}, X_{25}$ dan $X_{26}$ dengan kekuatan hubungan +0.216. (3) Ujian Akhir Semester/UAS bergerak kearah positif 0,252 merupakan agregasi $X_{10}$ dan $X_{12}$. (4) Administrasi terbentuk dari $X_{6}$ dan $X_{7}$ dengan pengaruhnya terhadap peningkatan kualitas layanan sebesar $8,3 \%$. (5) Laboratorium mempunyai angka korelasi 0,57 terbentuk dari $X_{2}$ dan $X_{3}$. (6) Ketrampilan terbentuk dari $X_{22}$. (7) Komunikasi terbentuk dari $X_{23}$. (8) Ruang kelas terbentuk $X_{1}, X_{11}$, dan $X_{17}$, (9) Waktu penyelesaian studi terbentuk $X_{14}$ (Ketepatan Waktu Studi) dengan angka korelasi faktor $-0,851$. Dapat diartikan bahwa jika kualitas pelayanan semakin tinggi maka ruang kelas akan lebih optimal dan waktu penyelesaian studi semakin pendek Ketiga:.Pada taraf nyata 0,05 penilaian responden terhadap kualitas layanan dan analisis keandalan alat ukur menggunakan reliability skala alpha memberikan hanya lima faktor yang dapat digunakan sebagai alat ukur yaitu: fasilitas $\left(F_{1}\right)$, jaminan pengetahuan $\left(F_{2}\right)$, jaminan ketrampilan $\left(F_{5}\right)$, empati dalam berkomunikasi $\left(F_{7}\right)$, dan keandalan waktu penyelesaian studi $\left(F_{9}\right)$. Dinyatakan dengan persamaan; $Y=0,493 F_{1}+0,448 F_{2}+9,14710^{-2} F_{5}+0,146$ $F_{6}+0,124 F_{7}+0,185 F_{9}-4.55510^{-16}$. Kekuatan hubungan 0,709 dengan 50,2\% variasinya.

Beberapa saran yang perlu diperhatikan adalah; (1) Penelitian ini hanya mengambil sampel pada saat mahasiswa berada berkelompok, kemungkian pengisiannya tidak independent besar, sehingga unsur objektif kurang sempurna. Agar lebih objektif di lakukan pada saat-saat tertentu dengan periode penjaringan data yang cukup lama dan menerus. (2) Hanya dapat digunakan dengan asumsiasumsi yang sama dengan kondisi di lingkungan Jurusan Teknik Sipil - FT. UNJ. (3) Perlu adanya perbaikan yang cukup terhadap kualitas pelayanan laboratorium, fasilitas pendukung lainnya serta kualitas sumber daya manusia 
non-akademik, yang pada akhirnya kualitas keseluruhan akan lebih baik. (4) Kesalahan interprestasi responden terhadap instrumen dapat diperkecil dengan menggunakan kata-kata yang lugas dan sederhana. Penelitian lanjutan sebaiknya juga melakukan pengambilan data melalui survey dengan teknik wawancara. (5) Penelitian lanjut juga dapat dilakukan untuk jurusan lain atau pada pelayanan tingkat fakultas teknik.

\section{DAFTAR PUSTAKA}

SPSS $\AA 10.0$ Syntax Reference Guide for SPSS Base, SPSS Regression Models, SPSS Advanced Models, USA: Microsoft Corporation. ImageStream, SPSS Inc,1999.

Achiffman LG, LL Kanuk, Consumer Behavior, $6^{\text {th }}$ Edition. Upper Saddle River, New Jersey: Prentice Hall, 1997

Chatfield., Christopher \& Collins., Alexander J., Introduction to Multivariate Analysis, Cambridge: Great Britain at University Press, 1992.

Dillon., William R and Goldstein., Matthew, Multivariate Analysis: Methods and Applications, USA: Jhon Wiley \& Sons, 1984.

Hines \& Montgomery, Probabilita dan Statistik dalam Rekayasa dan Manajemen, Edisi kedua, Jakarta: UI-Press, 1990.

Kotler P., Marketing Manajemen: Analysis, Planning, Implementation, and Control, $8^{\text {th }}$ edition. Englewood Cliffs, New Jersey: Prentice Hall International, 1994.

Miller \& Freund, Probability and Statistics for Engineers, Third Edition, USA: Prentice Hall: 1987

Wells., William D, and Prensky., David, Consumer Behaviour, New-York: Jhon Wiley \& Sons. Inc, 1996.

Kualitas Pelayanan di Jurusan Teknik Sipil FT-UNJ Dari Sudut Pandang Mahasiswa Sebagai Pelanggan.(Irika Widiasanti, Dosen Jurusan Teknik Sipil FTUNJ) 